\title{
Colonization by arbuscular mycorrhizal and fine endophytic fungi in herbaceous vegetation in the Canadian High Arctic
}

\author{
Pål Axel Olsson, Bente Eriksen, and Anders Dahlberg
}

\begin{abstract}
The occurrence of arbuscular mycorrhizal (AM) fungi was surveyed along a latitudinal gradient in Arctic Canada including Banks Island $\left(73^{\circ} \mathrm{N}\right)$, Devon Island $\left(74^{\circ} \mathrm{N}\right)$, Ellesmere Island $\left(76^{\circ} \mathrm{N}\right)$, and the Magnetic North Pole at Ellef Ringnes Island $\left(78^{\circ} \mathrm{N}\right)$. At Banks Island, AM fungi were present and colonized at a high intensity in all specimens of Potentilla hookeriana Lehm. - Potentilla pulchella R.Br., Arnica angustifolia Vahl, and Erigeron uniflorus L. ssp. eriocephalus (Vahl ex Hornen.) Cronq. sampled. The soil collected under these plants showed a high inoculum potential when tested at greenhouse conditions using Plantago lanceolata L. as a bait plant. Occasional occurrence of AM fungi was recorded in Festuca hyperborea Holmen ex Frederiksen, Trisetum spicatum (L.) Richt., and Potentilla hookeriana - Potentilla pulchella at Devon Island. Despite the fact that potential AM plants are present, no AM was found at the two most northern sites, Ellesmere Island and Ellef Ringnes Island. There seems to be climatic or dispersal limitations to AM colonization at these northern sites. Fine endophytic fungi, formerly named Glomus tenue (Grenall) I.R. Hall, were recorded at all four sites, but most frequently at Banks Island. We thereby provide further evidence that fine endophytes are more frequent in harsh climatic conditions than AM fungi. There was a relatively high proportion of nonmycorrhizal plant species at all sites, and this proportion increased towards the north.
\end{abstract}

Key words: arctic, arbuscular mycorrhiza, fine endophytes, dark septate fungi.

Résumé : Les auteurs ont examiné la présence des champignons mycorhiziens arbusculaires (AM), le long d'un gradient latitudinal dans l'Arctique canadien, incluant les îles de Banks $\left(73^{\circ} \mathrm{N}\right)$, de Devon $\left(74^{\circ} \mathrm{N}\right)$ et d'Ellesmere $\left(78^{\circ} \mathrm{N}\right)$, ainsi qu'au pôle nord magnétique sur l'île d'Ellef Ringnes $\left(78^{\circ} \mathrm{N}\right)$. Sur l'île de Banks, les champignons AM sont présents et colonisent fortement tous les spécimens échantillonnés des Potentilla hookeriana Lehm. - Potentilla pulchella R.Br., Arnica angustifolia Vahl. et Erigeron uniflorus L. ssp. eriocephalus (Vahl ex Hornen.) Cronq. Les sols récoltés sous ces plants montrent un fort potentiel inoculant, lorsque testés en serres en utilisant le Plantago lanceolata L. comme plant piège. On retrouve occasionnellement des champignons AM sur les Festuca hyperborea Holmen ex Frederiksen, Trisetum spicatum (L.) Richt. et Potentilla hookeriana - Potentilla pulchella, sur l'île de Devon. Bien qu'on y trouve des plantes aptes à former des AM, on ne retrouve aucune mycorhize sur les sites les plus nordiques des îles d'Ellesmere et d'Ellef Ringnes. Il semble qu'il y ait des limitations climatiques ou de dispersion, à la colonisation AM sur ces sites nordiques. On retrouve le champignon endophyte ténu, déjà nommé Glomus tenue (Grenall) I.R. Hall, sur tout les sites, mais surtout sur l'île de Banks. Conséquemment, les auteurs présentent d'autres preuves que les endophytes ténus sont plus fréquents sous les conditions climatiques sévères, que les champignons AM proprement dits. Il y a une proportion relativement forte d'espèces de plantes non-mycorhiziennes sur tous les sites, et cette proportion augmente en allant vers le nord.

Mots clés : arctique, mycorhize arbusculaire, endophytes ténus, champignons foncés à septations.

[Traduit par la Rédaction]

\section{Introduction}

The arbuscular mycorrhiza (AM) is the most widespread

Received 3 February 2004. Published on the NRC Research Press Web site at http://canjbot.nrc.ca on 16 November 2004.

P.A Olsson. ${ }^{1}$ Department of Microbial Ecology, Lund University, Ecology Building, SE-223 62 Lund, Sweden. B. Eriksen. Botanical Institute, Evolutionary Botany, University of Göteborg, P.O. Box 461, SE-405 30, Göteborg, Sweden.

A. Dahlberg. ArtDatabanken, Swedish Species Information Center, P.O. Box 7007, SE-750 07 Uppsala, Sweden.

${ }^{1}$ Corresponding author (e-mail: pal_axel.olsson@mbioekol.lu.se). and ancient form of mycorrhiza (Smith and Read 1997). It occurs in about $70 \%$ of all vascular plant species on earth and is the most abundant mycorrhizal form in the majority of temperate and tropical ecosystems. Arctic and alpine ecosystems have a species-poor vegetation mostly dominated by species from a few genera such as Eriophorum, Carex, Betula, Dryas, Salix, Vaccinium, and Empetrum (Gardes and Dahlberg 1996). The arbuscular mycorrhiza is considered to be of minor importance in these ecosystems, because these dominant plants are typically nonmycorrhizal or form other types of mycorrhizas than AM (Smith and Read 1997).

Previous studies of mycorrhizas in arctic areas indicate that AM may be rare, even when potential host plants are present. On Svalbard (around $78^{\circ}$ N, Fig. 1, site 2), 76 plant species were surveyed for AM, and none of these were colo- 
Fig. 1. Location of the four study sites at Banks Island, Devon Island, Ellesmere Island, and Ellef Ringnes Island (O). The locations of earlier study sites are also indicated (O) as follows: 1, Barrow, Alaska (Miller and Laursen 1978); 2, Svalbard (Väre et al. 1992); 3, Eureka, Ellesmere Island (Dalpé and Aiken 1998); 4, Headland, Axel Heiberg Island (Dalpé and Aiken 1998); 5, Alexandra Fiord on Ellesmere Island (Bledsoe et al. 1990; Kohn and Stasovski 1990); 6, Devon Island (Bledsoe et al. 1990); 7, Polar Bear Pass, Bathurst Island (Dalpé and Aiken 1998); 8, Iceland (Greipsson et al. 2002).

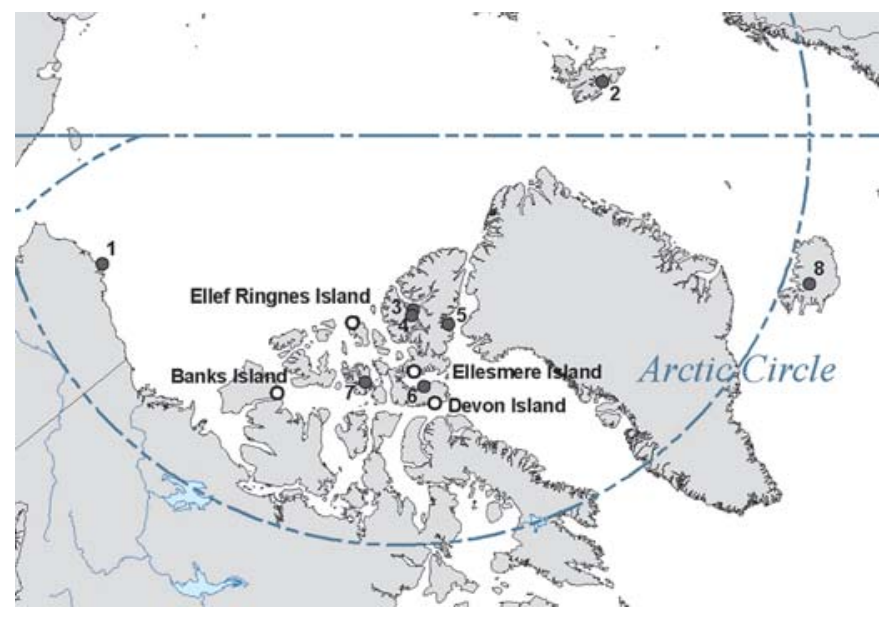

nized, although at least 30 of the species could be expected to have AM (Väre et al. 1992). The only record of AM fungi was one spore found in a soil sample. Furthermore, Bledsoe et al. (1990) did not find any clear evidence for AM in Arctic Canada, although 13 potential AM species (12 grasses and Ranunculus sulphureus) were investigated at Truelove Lowland on Devon Island $\left(75^{\circ} \mathrm{N}\right.$, Fig. 1, site 6) and at Alexandra Fiord on Ellesmere Island ( $78^{\circ} \mathrm{N}$, Fig. 1, site 5). The only indication of AM was the coiled hyphae similar to AM peletons observed in $R$. sulphureus. Other studies do, however, give evidence for occurrence of AM at high latitudes. Dalpé and Aiken (1998) found AM colonization of Festuca brachyphylla on Ellesmere Island and other places in Arctic Canada around $80^{\circ} \mathrm{N}$ (Fig 1, sites 3, 4, and 7), but the colonization never reached a higher level than $15 \%$. Identified AM fungal species were Glomus aggregatum, Glomus fasciculatum, Glomus macrocarpum, and Glomus mosseae. At Alexandra Fiord (Fig. 1, site 5), AM colonization has been found in Dryopteris fragrans, whereas it is seemingly absent in several other possible AM plants (Kohn and Stasovski 1990), and Miller and Laursen (1978) found AM colonization in Ranunculus species at Barrow, Alaska (Fig. 1, site 1).

Fine endophytes and dark septate fungi are two other groups of fungi living in symbiosis with the same plants that form AM. The function and taxonomical status of fine endophytes are still largely unknown. They were earlier classified as glomalean fungi, under the name Glomus tenue. They are widespread as symbionts with the same host plants as AM fungi (Thippayarugs et al. 1999). Dark septate fungi have previously been found to colonize a range of alpine plants (Read and Haselwandter 1981) and they are also common in arctic areas such as Svalbard, where they were the most common fungal structure, found in 30 of 76 plant species studied (Väre et al. 1992). These fungi are probably ascomycetes and parasites on plant roots (Jumpponen and Trappe 1998). Stoyke et al. (1992) showed that the dominant dark septate fungus in a range of plants in a subalpine area in the Rocky Mountains in Canada was Phialophora fortinii.

In 1999, we participated in a ship-based multidisciplinary international research expedition in the Canadian Arctic, Tundra NorthWest 1999, arranged by the Swedish Polar Research Secretariat under the Royal Swedish Academy of Sciences. The expedition focused on studies of the ecology of the tundra and visited sites selected to represent a longitudinal and latitudinal gradient of the area and to encompass vegetation within the High Arctic zones (Molau et al. 1999). The High Arctic is distinguished from the Low Arctic on the basis of ecological criteria, including a shorter growing season, cooler summers, and a marked reduction in biotic diversity (Elvebakk 1999). We took this opportunity to collect plants and soils to search for the presence and distribution of AM fungi in the Arctic. We were especially searching for plant species that are typically AM hosts, such as members of the Asteraceae, Rosaceae, Onagraceae, and Poaceae families (see Harley and Harley 1987; Väre et al. 1997). The conventional view that the presence of AM fungi is crucial for the establishment of many plant species (Van der Heijden 2002) and enhances plant diversity (Van der Heijden et al. 1998) suggests that the presence or absence of AM fungi will influence the plant community composition of these arctic ecosystems.

The main objective of this study was to test the hypothesis that AM colonization can be intensive in arctic habitats where the vegetation is similar to intensively AM-colonized vegetation at lower latitudes (such as grasslands with a high $\mathrm{pH}$ and a high proportion of forbs). We also determined whether arctic AM plants may be present without AM fungi at the border of their climatic distribution, and assessed the presence of AM colonization in relation to two other groups of symbiotic fungi, fine endophytes, and dark septate fungi. As an alternative approach of indicating the importance of AM at different sites, we estimated the relative success of typically mycorrhizal and nonmycorrhizal plants (Peat and Fitter 1993). Although species of typically nonmycorrhizal families may form AM, their normal status is nonmycorrhizal (Harley and Harley 1987). Growth of these species may even be inhibited by the presence of AM fungal mycelium (Francis and Read 1995; Johnson 1998). It is known that nonmycorrhizal plant species are common in highly disturbed areas in temperate climates (Francis and Read 1994). Disturbance selects for species with short life cycles (Grime 1979), and such species are often nonmycorrhizal. In contrast, AM plants are selected for in more stable systems where the efficient use of nutrients is advantageous. Arctic habitats are characterized by extreme conditions. Low temperature and a short growing season limit plant growth. Although there is little anthropogenic disturbance, soils are highly unstable because of repeated cycles of freezing and thawing, causing disturbance of the vegetation (Grime 1979). Diurnal oscillations in soil temperature around the freezing point is likely to be most prevalent at higher latitudes where temperatures are low and insolation during midday is high. Hence, soil disturbances are expected to increase in frequency and intensity towards the north. Like in 
Table 1. Soil properties at mesic locations at the different sites in Arctic Canada.

\begin{tabular}{llllllc}
\hline Site & $\mathrm{pH}$ & $\begin{array}{l}\text { Water } \\
(\%)\end{array}$ & $\begin{array}{l}\text { LOI } \\
(\%)\end{array}$ & $\begin{array}{l}\text { Total N } \\
\left(\mathrm{mg} \cdot \mathrm{g}^{-1}\right)\end{array}$ & $\begin{array}{l}\text { Total P } \\
\left(\mathrm{mg} \cdot \mathrm{g}^{-1}\right)\end{array}$ & $\begin{array}{l}\text { Organic C } \\
\left(\mathrm{mg} \cdot \mathrm{g}^{-1}\right)\end{array}$ \\
\hline Banks Island & 7.0 & 44 & 19 & 4.7 & 0.58 & 56 \\
Devon Island & 6.3 & 66 & 53 & 1.1 & $1.2^{*}$ & 97 \\
Ellesmere Island & 7.3 & 13 & 5 & 0.9 & 0.17 & 8.1 \\
Ellef Ringnes Island & $\mathrm{nda}^{\dagger}$ & 19 & 8 & 2.0 & 0.50 & 27 \\
\hline
\end{tabular}

\footnotetext{
Note: Data from M. Bölter, H.-P. Blume, and H. Wetzel (unpublished data, used with permission from M. Bölter). LOI, loss on ignition.

*No data were available for mesic sites; therefore, the data from the dry site were used.

${ }^{\dagger}$ nda, no data available.
}

temperate areas, disturbance in the Arctic is followed by release of nutrients (Jonasson and Sköld 1983). We expect to find many nonmycorrhizal, disturbance-selected plant species favoured at these sites.

\section{Materials and methods}

\section{Study sites}

We sampled plants and soil at four sites in the Canadian Arctic Archipelago: within the Middle arctic tundra zone, southern Devon Island $\left(74^{\circ} 33^{\prime} \mathrm{N}, 82^{\circ} 48^{\prime} \mathrm{W}\right)$, within the Northern arctic tundra zone, northern Banks Island $\left(73^{\circ} 37^{\prime} \mathrm{N}, 115^{\circ} 50^{\prime} \mathrm{W}\right)$, and southern Ellesmere Island $\left(76^{\circ} 28^{\prime} \mathrm{N}, 86^{\circ} 55^{\prime} \mathrm{W}\right)$, and within the Arctic polar desert zone, the Magnetic North Pole at Ellef Ringnes Island $\left(78^{\circ} 56^{\prime} \mathrm{N}\right.$, $104^{\circ} 39^{\prime} \mathrm{W}$ ) (Fig. 1). The zonal division of the Arctic is in accordance with the suggestion by Elvebakk (1999).

The Banks Island coastal plain has a mean annual temperature of $-14{ }^{\circ} \mathrm{C}$ and a summer mean temperature of $1{ }^{\circ} \mathrm{C}$ (Angerbjörn 1998). The temperature is moderated by open water during late summer and early autumn. Mean annual precipitation is $100-200 \mathrm{~mm}$. The permafrost is deep and continuous with high ice content. Vegetation with mosses and low-growing herbs and shrubs dominates. The mean annual temperature is $-18{ }^{\circ} \mathrm{C}$, and the mean summer temperature is $-2{ }^{\circ} \mathrm{C}$ at Ellesmere and Devon Islands, and the mean annual precipitation ranges from 200 to $300 \mathrm{~mm}$. Salix and Dryas spp. occur frequently. Ellef Ringnes Island is characterized by low relief and a sparse vegetation lacking lignified species, such as Salix and Dryas spp. The mean annual temperature is $-18{ }^{\circ} \mathrm{C}$, and the mean summer temperature is $1.5^{\circ} \mathrm{C}$. Deep continuous permafrost prevails. Mean annual precipitation is $100-150 \mathrm{~mm}$. The dominant vegetation consists of cold-hardy vascular plants, mosses, and lichens. See Table 1 for general soil characteristics.

\section{Sampling}

Plants were collected from Banks Island (12 August 1999), Devon Island (26 August 1999), Ellesmere Island (22 August 1999), and Ellef Ringnes Island (19 August 1999), and several plant specimens of each species were collected when possible (see Table 1). In general, samples were collected within an area of $1 \mathrm{~km}^{2}$, and replicate samples were taken at a distance of at least $50 \mathrm{~m}$ from each other. Plant specimens on root were stored frozen at $-18{ }^{\circ} \mathrm{C}$ until staining. Beneath each plant sampled, ca. $1 \mathrm{~kg}$ of soil was removed and transferred to plastic bags. The bags were stored at $+4{ }^{\circ} \mathrm{C}$ for 27 weeks until the onset of the experiment with bait seedlings started in March 2000.

\section{Fungal root colonization and presence of AM fungal spores}

Roots were stained according to a protocol modified from the method described by Phillips and Hayman (1970). A subsample of fine roots from either the original plants or the bait plants was washed free from soil and heated to $80{ }^{\circ} \mathrm{C}$ in $10 \% \mathrm{KOH}$ until sufficiently cleared. After rinsing in water, roots were stained at room temperature in $0.1 \%$ Trypan blue in lactic acid, glycerol, and water (1:1:1, by volume), rinsed in water, and destained in 50\% glycerol. The magnified intersections method, as described by McGonigle et al. (1990), was used to determine the total proportion of the root length with AM fungal root colonization and the frequency of AM fungal arbuscules and vesicles. The proportion of root length colonized by fine endophytic fungi (Thippayarugs et al. 1999) and dark septate fungi (Jumpponen and Trappe 1998) was also detetermined from the samples used to determine AM colonization. All microscopical determinations were made at 250x magnification using a Zeiss Standard microscope. Micrographs were recorded at $250 \times$ or $400 \times$ magnification on a 400 ASA film with a Zeiss microscope camera. The term fine endophytes includes symbiotic fungi formerly named Glomиs tenиe (Grenall) I.R. Hall. We investigated the presence of spores in the soil samples from Banks Island by wet sieving with a $25-\mu \mathrm{m}$ pore-sized mesh (Gerdemann and Nicolson 1963).

\section{Inoculum potential experiment}

Soil at field moisture was placed in plastic pots $(200 \mathrm{~g}$ in each), and three Plantago lanceolata L. seedlings were planted in each pot. The plants were grown for 12 weeks in a greenhouse under the following conditions: $23{ }^{\circ} \mathrm{C}$ day : $20{ }^{\circ} \mathrm{C}$ night temperature, $60 \%$ relative humidity, and $150 \mu \mathrm{mol} \cdot \mathrm{m}^{-2} \cdot \mathrm{s}^{-1}$ photosynthetic photon flux density $16 \mathrm{~h}$ per day. Biomass productivity was estimated as the dry biomass of one Plantago lanceolata shoot after 12 weeks of growth in the soil at field capacity moisture. The roots were rinsed, and the AM fungal root colonization was estimated. The $\mathrm{pH}$ of the soils was measured at harvest of the bait plant experiment.

\section{Vegetation data}

At each location, two adjacent areas with contrasting plant cover were selected. One of them had closed vegetation and 
Fig. 2. Arnica angustifolia colonized by AM fungi at Banks Island. (a) Hyphal and arbuscular colonization. (b) Vesicular and arbuscular colonization. (c) Intraradical spores. (d) Vesicles. (e) Intraradical spores and vesicles. Scale bars $=35 \mu \mathrm{m}$.

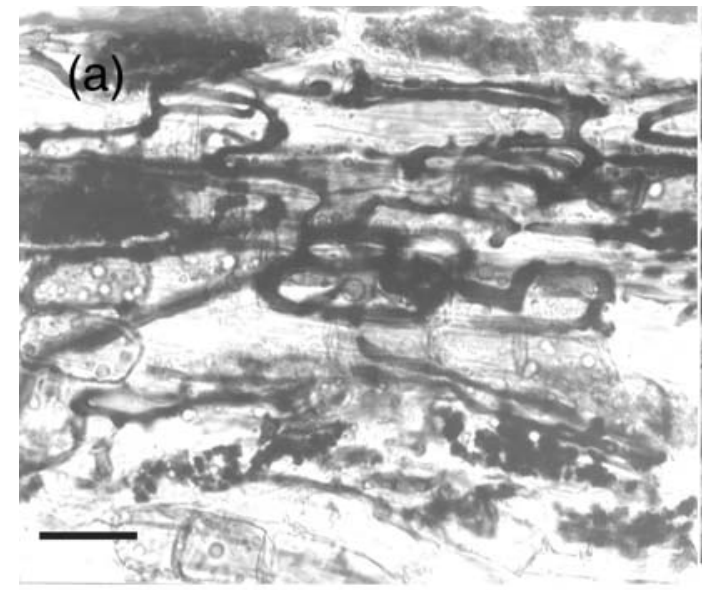

(d)

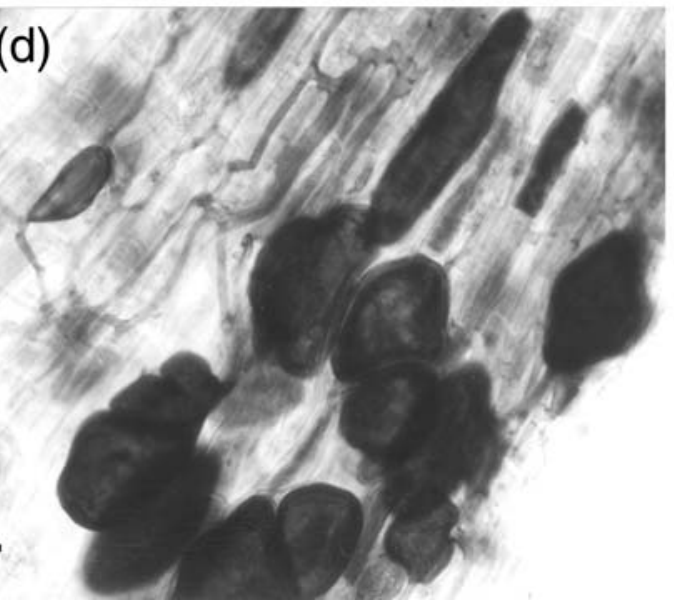

was classified as a mesic situation, the other had open vegetation and was classified as dry. A $20 \mathrm{~m} \times 20 \mathrm{~m}$ plot was established in each area. Within the $400-\mathrm{m}^{2}$ plot, ten $0.25-\mathrm{m}^{2}$ quadrats were randomly selected and marked. Point frames with wires at $10 \mathrm{~cm}$ distance ( 25 points) were applied to the quadrats, and the vascular plant species hit at each point were noted. A total species list for each quadrat and for the $20 \mathrm{~m} \times 20 \mathrm{~m}$ square plot was made. Total species lists of observed species at the site were compiled from the results for the plots, collections in the area outside the plots (including wet habitats), and field notes on occurrences. The area outside the plots was inventoried by noting species occurreces while walking $8-10 \mathrm{~h}$ across the landscape, and corresponds approximately to a $10-\mathrm{km}$ transect. The nomenclature is based on Porsild and Cody (1980) but has been modified to follow the checklist of vascular plants compiled by the Panarctic Flora project members.

Mycorrhizal status of plant species was designated according to (Harley and Harley 1987). Species belonging to the families Brassicaceae, Caryophyllaceae, Crassulaceae, Cyperaceae, Juncaceae, Chenopodiaceae, Polygonaceae, Saxifragaceae, Papaveraceae, and the hemiparasitic Scrophulariaceae (including for example Pedicularis) were considered as nonmycorrhizal species (Harley and Harley 1987; Moore 1987; Newman and Reddell 1987; Tester et al. 1987). Pteridiophytes were not classified as belonging to either of the mycorrhiza types (see Harley and Harley 1987) and are therefore reported as a separate group.

\section{Results}

\section{Colonization by AM fungi}

The three plant species collected at Banks Island were in all cases colonized by AM fungi (Table 1). AM colonization in Potentilla hookeriana Lehm. - Potentilla pulchella R.Br., and Erigeron uniflorus L. ssp. eriocephalus (Vahl ex Hornem.) Cronq. was over $80 \%$ and thereby clearly higher than the colonization in Arnica angustifolia Vahl, reaching only half that value. Potentilla hookeriana and Potentilla pulchella both occur in the area, and so does their hybrid (B. Eriksen and M. Andersson, unpublished data). Hence, we name the taxa collectively Potentilla hookeriana Potentilla pulchella. Vesicular colonization was similar in the three species, while arbuscular colonization varied widely among them. The ease with which arbuscules are detected in different species varies, and this difference could explain part of the variation seen among the species examined here. The roots of Arnica angustifolia were mainly of two distinct size classes. The thinner roots (ca. $0.3 \mathrm{~mm}$ diam.) were colonized by AM, while the thicker roots (ca. 1-mm diam.) were uncolonized. Only a small amount of H-connected hyphae was seen in Arnica angustifolia (Fig. 2a), while arbuscules 
Fig. 3. Erigeron eriocephalus colonized by AM at Banks Island. (a) Hyphal colonization. (b) Vesicles. Scale bars $=35 \mu \mathrm{m}$.
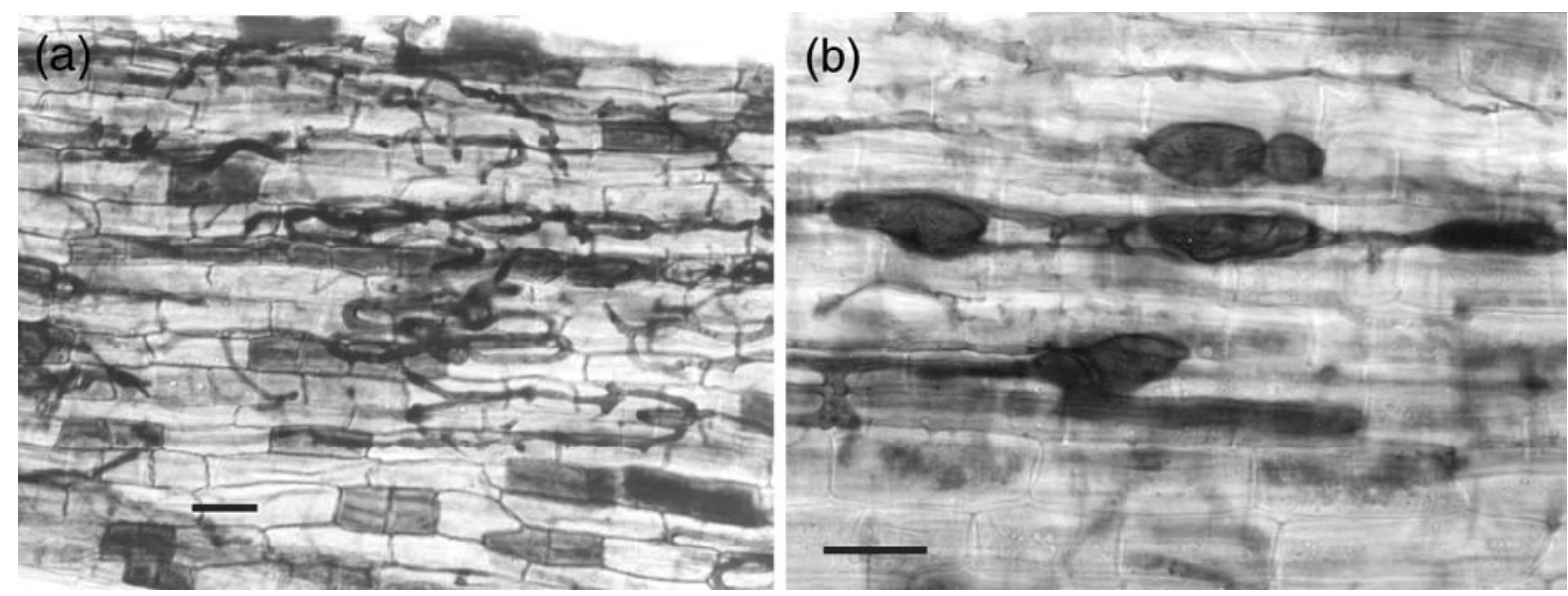

Fig. 4. Colonization by fine endophytes. (a) Trisetum spicatum at Ellesmere Island. (b) Fine endophytes together with AM fungal hyphae in Arnica angustifolia. Scale bars $=35 \mu \mathrm{m}$.

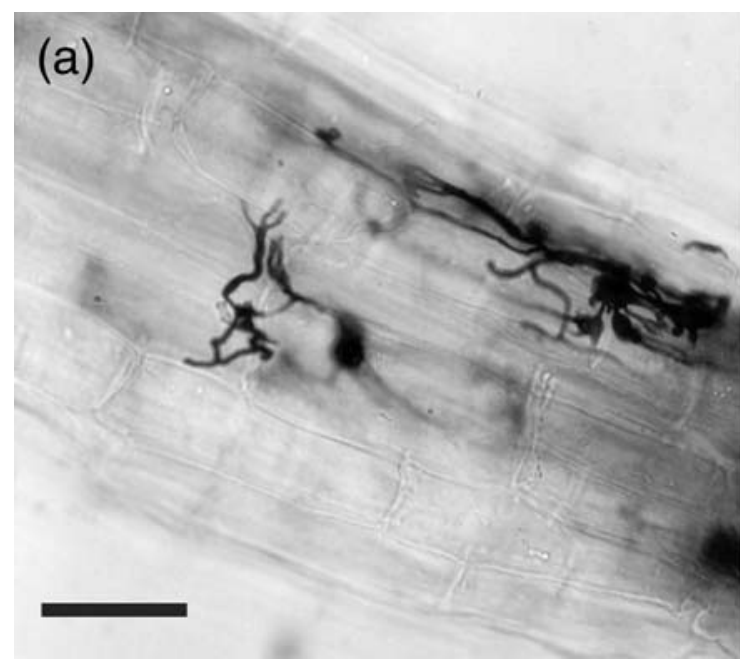

were common (Fig. 2b). Intensive vesicular colonization was often seen in Arnica angustifolia (Fig. 2d), and intraradical Glomus spores were common (Figs. $2 c$ and $2 e$ ). Intraradical spores are distinguished from vesicles by their larger size and thicker wall. The colonization of Erigeron uniflorus was characterized by frequent occurrence of $\mathrm{H}$ connected hyphae (Fig. 3a). There was a high level of arbuscular colonization in Erigeron uniflorus (Fig. 3b). Vesicular colonization was intense in many cases, sometimes with elongated irregularly shaped vesicles (Fig. 3b). Intraradical Glomus spores occurred frequently in Erigeron uniflorus. In colonized parts of Potentilla hookeriana Potentilla pulchella roots, the hyphal colonization was very intense with $\mathrm{H}$-connected hyphae. The low frequency of arbuscules in this species could be a result of problems with detecting them because of dark roots and intensive hyphal colonization. AM fungal spores were frequently found in the soil samples from Banks Island. Most spores had remains of the subtending hyphae, and these could be identified as pertaining to the genus Glomus, because the spore wall was continuous with the subtending hyphae. Some spores were without subtending hyphae, and they could either belong to

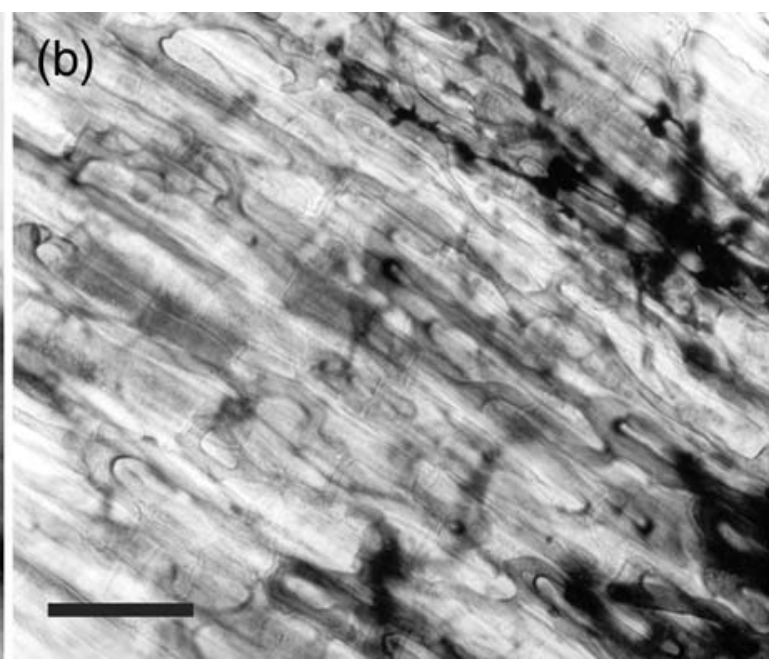

the Glomus or the Acaulospora genus. The predominant type of Glomus spores was small (less than $50 \mu \mathrm{m}$ diam.).

AM fungal colonization was absent in plants sampled at Ellef Ringnes and Ellesmere Islands, while occasional and low AM colonization was recorded in plants from Devon Island. Colonized species at Devon Island were Festuca hyperborea Holmen ex Frederiksen, Trisetum spicatum (L.) Richt., and Potentilla hookeriana - Potentilla pulchella. Arbuscular, vesicular, and hyphal colonization was seen in these plants, but no intraradical spores were observed.

\section{Colonization by fine endophytes and dark septate fungi}

Colonization by fine endophytes was found in all the plant species at Banks Island, although only to a very low extent in Potentilla hookeriana - Potentilla pulchella (Table 1). Fine endophytes were found at all four sites, but occurred less often at the three northernmost sites. In three cases the colonized species were grasses (see Fig. $4 a$ for colonization in Trisetum spicatum), but also the forb Ranunculus sabinei R.Br. at Ellef Ringnes Island had a very high colonization by fine endophytes. Fine endophytes were also observed in roots otherwise heavily colonized by AM fungi, such as in 
Fig. 5. $\mathrm{pH}$ of soils and biomass production by Plantago lanceolata in the bait plant experiment. Error bars represent SD. Numbers of replicates are the same as those given in Table 1.

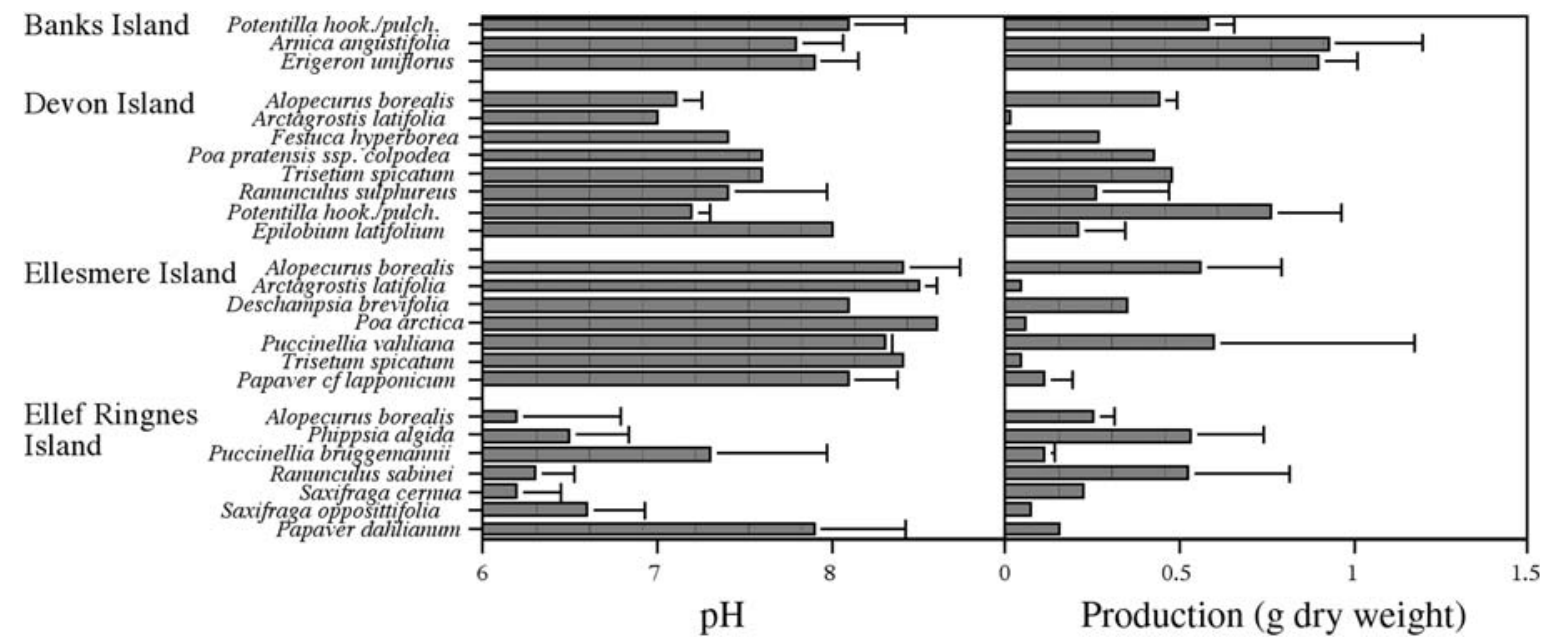

Arnica angustifolia (Fig. 4b). Plants colonized with dark septate fungi were in many cases identical to those either colonized by AM fungi or by fine endophytes. The only exception is the colonization by fine endophytes in Puccinellia vahliana (Liebm.) Scribn. \& Merr. at Ellesmere Island (Table 1).

\section{Colonization of bait plants}

Soil collected under each of the investigated plant specimens was tested for its inoculum potential by planting seedlings of Plantago lanceolata as bait plants. All soils from Banks Island contained inoculum of both AM fungi and fine endophytic fungi as seen by their colonization in Plantago lanceolata (Table 1). This result was congruent with the high AM and fine endophyte colonization found in the original plant material from Banks Island. The only other site where soil had AM fungal inoculum potential in bait plants was Devon Island. Presence of the fungi had been revealed by the fact that plants sampled in the area were colonized to some extent. Soils collected under colonized plants had inoculum potential, but also some soils collected under plants that were not colonized carried the inoculum potential. Colonization of the bait plants Plantago lanceolata in Devon soils was higher than in the plants growing at the site, whereas this was not the case for the soils from Banks Island. The bait plant experiment confirmed that the sites at Ellesmere and Ellef Ringnes Islands contained fine endophytic fungi and that no AM fungi could be demonstrated. A fine endophytic fungus was also found in one soil sample collected beneath a typical nonmycorrhizal plant (Saxifraga cernua L.). There was no colonization of dark septate fungi in the bait plants.

\section{pH and plant biomass productivity}

At Banks Island, Ellesmere Island and Devon Island, the $\mathrm{pH}$ was in all cases above 7, while at Ellef Ringnes Island the $\mathrm{pH}$ was in most cases between 6 and 7 (Fig. 5a). In general there was low variation in $\mathrm{pH}$ in soils of the same plant species. The major exception was at Ellef Ringnes Island, where high variation in $\mathrm{pH}$ in soils of the same plant species was observed. At Ellef Ringnes Island, there was also a con- siderable overall variation in $\mathrm{pH}$, and two species, Papaver dahlianum Nordh. and Puchinella bruggemannii Th.Sør., grew in places with much higher $\mathrm{pH}$ than the other collected plants. The shoot biomass production of Plantago lanceolata was highest in the soils from Banks Island (Fig. 5b). There was no relation between $\mathrm{pH}$ and plant productivity $(r=$ $0.005)$, but there was a significant positive relation between plant productivity and AM colonization when the samples from Banks Island and Devon Island were tested $(r=0.40$, $p>0.05, n=25)$.

\section{Occurrence of nonmycorrhizal plants}

An analysis of the vegetation data from surveys at the different sites revealed that the proportion of species that is considered to be typically nonmycorrhizal was high at all sites (Table 2). Furthermore, the proportion of nonmycorrhizal species increased from the Middle and Northern Arctic zone to the Arctic polar desert zone with the highest proportion recorded at Ellef Ringnes Island (Table 2). At all these sites the number of nonmycorrhizal and AM plant species was much higher than the number of plants with other mycorrhizal types. The vegetation cover was estimated in selected plots in dry or mesic habitats (Table 3 ). The vegetation cover was low in dry plots at all sites (Table 4). In plots with mesic vegetation, the vegetation cover was at least $50 \%$, except for at Ellef Ringnes Island. The proportion of vegetation cover by nonmycorrhizal species varied greatly among plots, mainly because of either dominance by grasses (AM) or Carex spp. (nonmycorrhizal) at different plots. Vegetation cover by nonmycorrhizal plant species was in most cases higher than cover by AM species. Ericoid and ectomycorrhizal plants were most common at Devon Island, while no such plants occurred at Ellef Ringnes Island.

\section{Discussion}

Until rather recently it was believed that $\mathrm{AM}$ is rare or infrequent in arctic areas, since AM had not been found consistently in any type of vegetation (Gardes and Dahlberg 1996). However, Dalpé and Aiken (1998) studied AM colonization in Festuca brachyphylla Schult. at several sites in 
Table 2. Colonization of plants collected at the different sites in Arctic Canada by arbuscular mycorrhizal fungi (AM), fine endophytic fungi (FE), and dark septate fungi (DSF).

\begin{tabular}{|c|c|c|c|c|c|c|c|c|c|}
\hline \multirow[b]{2}{*}{ Site and plant species } & \multicolumn{5}{|c|}{ Colonization of original plants $(\%)$} & \multicolumn{4}{|c|}{ Colonization of bait plants $(\%)$} \\
\hline & $\begin{array}{l}\text { Total } \\
\text { AM }\end{array}$ & $\begin{array}{l}\text { Arbuscular } \\
\text { AM }\end{array}$ & $\begin{array}{l}\text { Vesicular } \\
\text { AM }\end{array}$ & FE & DSF & $\begin{array}{l}\text { Total } \\
\text { AM }\end{array}$ & $\begin{array}{l}\text { Arbuscular } \\
\text { AM }\end{array}$ & $\begin{array}{l}\text { Vesicular } \\
\text { AM }\end{array}$ & FE \\
\hline $\begin{array}{l}\text { Potentilla hookeriana - } \\
\quad \text { Potentilla pulchella (4) }\end{array}$ & $85 \pm 13$ & $0.8 \pm 1.6$ & $16 \pm 12$ & $0.8 \pm 1.5$ & - & $46 \pm 26$ & $27 \pm 20$ & $2.3 \pm 3.9$ & $8.1 \pm 9.5$ \\
\hline Arnica angustifolia (5) & $37 \pm 34$ & $7.9 \pm 11$ & $14 \pm 11$ & $3.6 \pm 5.1$ & $17 \pm 33$ & $41 \pm 13$ & $19 \pm 11$ & $4.9 \pm 2.1$ & $5.4 \pm 5.0$ \\
\hline \multicolumn{10}{|l|}{ Devon Island $\left(74^{\circ} \mathrm{N}\right)$} \\
\hline Alopecurus borealis (2) & - & - & - & - & - & $0-33$ & $0-32$ & - & $0-4.0$ \\
\hline Arctagrostis latifolia (1) & - & - & - & - & - & - & - & - & - \\
\hline Festuca hyperborea (1) & 1.6 & - & - & 3.4 & 3.4 & 20 & 20 & - & - \\
\hline Poa pratensis ssp. colpodea (1) & - & - & - & - & - & 40 & 38 & - & - \\
\hline Epilobium latifolium (2) & - & - & - & - & - & - & - & - & - \\
\hline \multicolumn{10}{|l|}{ Ellesmere Island $\left(76^{\circ} \mathrm{N}\right)$} \\
\hline Alopecurus borealis (3) & - & - & - & - & - & - & - & - & - \\
\hline Arctagrostis latifolia (3) & - & - & - & - & - & - & - & - & - \\
\hline Deschampsia brevifolia (1) & - & - & - & - & - & - & - & - & 4.2 \\
\hline Poa arctica (1) & - & - & - & - & - & - & - & - & - \\
\hline Puccinellia vahliana (2) & - & - & - & - & $0-1.5$ & - & - & - & - \\
\hline Trisetum spicatum (1) & - & - & - & 52 & 1.9 & - & - & - & 11 \\
\hline Papaver cf. lapponicum (2) & - & - & - & - & - & - & - & - & - \\
\hline \multicolumn{10}{|l|}{ Ellef Ringnes Island $\left(78^{\circ} \mathbf{N}\right)$} \\
\hline
\end{tabular}

Note: Soil was collected under each original plant individual and planted with Plantago lanceolata seedlings to reveal the inoculum potential, measured as colonization of bait plants. Total, arbuscular, and vesicular colonization were estimated for AM fungi. No colonization by DSF was found in bait plants. The number of replicates is given in parenthesis for each species (mean \pm SD). Nomenclature follows Porsild and Cody (1980). Sites are listed from south to north.

Table 3. Proportion of typically nonmycorrhizal (NM), arbuscular mycorrhizal (AM), ericoid, and ectomycorrhizal (EM) species and Pteridiophyta (\%) among the species found at the different sites (Harley and Harley 1987).

\begin{tabular}{lllllll}
\hline Site & $\begin{array}{l}\text { No. of } \\
\text { species }\end{array}$ & $\begin{array}{l}\text { NM } \\
(\%)\end{array}$ & $\begin{array}{l}\text { AM } \\
(\%)\end{array}$ & $\begin{array}{l}\text { Ericoid } \\
(\%)\end{array}$ & $\begin{array}{l}\text { EM } \\
(\%)\end{array}$ & $\begin{array}{l}\text { Pteridiophyta } \\
(\%)\end{array}$ \\
\hline Banks Island & 121 & 52 & 43 & 0 & 2.5 & 2.5 \\
Devon Island & 106 & 62 & 29 & 1.9 & 2.8 & 3.8 \\
Ellesmere Island & 49 & 69 & 24 & 0 & 4.1 & 2.0 \\
Ellef Ringnes Island & 26 & 73 & 27 & 0 & 0 & 0 \\
\hline
\end{tabular}

the Northern Arctic tundra zone (ca. $80^{\circ}$ N, Fig. 1). They reported colonization in many cases, but it was infrequent compared with the colonization they found in Festuca baffinensis Polunin at Bathurst Island (around $75^{\circ}$ N, Fig. 1, site 7). We confirmed by this study that AM fungi can occur frequently in arctic areas and we show that the AM colonization may be intensive also in the Arctic. Kohn and Stasovski (1990) found only occasional AM colonization in Dryopteris fragrans (L.) Schott and not in any other plant at Alexandra Fiord on Ellesmere Island (at $78^{\circ} 57^{\prime} \mathrm{N}$, Fig 1, site 
Table 4. Proportion of cover in dry and mesic vegetation plots.

\begin{tabular}{lllrrrrl}
\hline Site & $\begin{array}{l}\text { Vegetation } \\
\text { plot }\end{array}$ & $\begin{array}{l}\text { Vegetation } \\
\text { cover }(\%)\end{array}$ & $\begin{array}{l}\text { NM } \\
(\%)\end{array}$ & $\begin{array}{l}\text { AM } \\
(\%)\end{array}$ & $\begin{array}{l}\text { Ericoid } \\
(\%)\end{array}$ & $\begin{array}{l}\text { EM } \\
(\%)\end{array}$ & $\begin{array}{l}\text { Pteridiophyta } \\
(\%)\end{array}$ \\
\hline Banks Island & Dry & 12 & 73 & 17 & 0 & 10 & 0 \\
& Mesic & 67 & 60 & 20 & 0 & 20 & 0 \\
Devon Island & Dry & 21 & 37 & 0 & 2 & 61 & 0 \\
& Mesic & 51 & 23 & 2 & 27 & 48 & 0 \\
Ellesmere Island & Dry & 2 & 50 & 0 & 0 & 50 & 0 \\
& Mesic & 50 & 60 & 17 & 0 & 20 & 3 \\
Ellef Ringnes & Dry & 5 & 0 & 100 & 0 & 0 & 0 \\
Island & Mesic & 16 & 74 & 26 & 0 & 0 & 0 \\
\hline
\end{tabular}

Note: There were 250 total records for each plot. Proportion of cover by typically nonmycorrhizal (NM), arbuscular mycorrhizal (AM), ericoid, and ectomycorrhizal (EM) species and Pteridiophyta (\%).

5). They also pointed out that there were few typical AM plants. It appears as if sites with and without AM-colonized plants occur in the same regions in the Arctic (Fig. 1). Sites without AM have been found on Devon Island and Ellesmere Island, while AM has been found also on these islands in other studies. These findings suggest that there is a critical limit for the formation of AM symbiosis within the Northern arctic tundra zone. This could either be due to dispersal limitations, or because the environmental conditions may limit a persistent establishment of vegetation harbouring AM fungi. Increasing proportions of vegetationless land at high latitudes may prolong the time needed for AM fungal dispersal, because the increasing distance between spots of vegetation becomes an obstacle, at least for wind dispersal. In succession on deglaciated land in Alaska, AM seems to disperse slower than ectomycorrhizal fungi (Helm et al. 1996). Hence, we do not know if AM fungi yet have reached as far in the Arctic as they potentially can after the retreat of the last ice. The investigation in antarctic areas by Christie and Nicolson (1983) showed a similar trend as we have described for the Arctic: AM fungi can be abundant in antarctic cold areas, but the frequncy is very low at the most polar sites. AM fungal root colonization was high in several plants on the subantarctic island of South Georgia, but none of the plants collected at South Orkney Island were colonized. Christie and Nicolson (1983) found no colonization of Deschampsia antarctica on the Antarctic Peninsula, while Cabello et al. (1994) managed to isolate a Glomus species from this area.

At a global scale, the relative number and abundance of AM plants generally decreases with increasing latitude (Smith and Read 1987; Gardes and Dahlberg 1996); and high latitude environments are often dominated by nonmycorrhizal sedges (Cyperaceae) or plants with ectomycorrhiza or ericoid mycorrhiza. Where frequent disturbances influence the vegetation, species of the nonmycorrhizal families Saxifragaceae, Caryophyllaceae, and Brassicaceae are often common. The relative abundance of nonmycorrhizal plant species were high throughout the sites we visited in the Arctic Canada, and the proportion of nonmycorrhizal plants was much higher $(52 \%-73 \%)$ than normally found in temperate grassland vegetation (Table 2). For example, in European dry calcareous grassland, around $15 \%$ of the plants are nonmycorrhizal, and the figure is around 30\% in alpine grasslands (Peat and Fitter 1993). The high proportion of nonmycorrhizal species at the arctic sites is similar to that expected in highly disturbed areas, where mainly plant species with short life cycles occur (Francis and Read 1994). Many Asteraceae species are highly dependent on AM, while grasses often seem to be less dependent, although they are well colonized in most ecosystems (Van der Heijden 2002). Whether species, which are considered to depend on AM for seedling establishment in grasslands, live without $\mathrm{AM}$ at high latitudes is not known. The absence of AM fungi at some of the northern sites may prevent certain plant species from colonizing these areas. We could, however, see that one of the plants, Potentilla hookeriana - Potentilla pulchella, was highly colonized at Banks Island and was only occasionally colonized at Devon Island. In contrast, the bait plants were colonized with equal intensity, suggesting that the soil conditions were not responsible for the lower colonization at Devon Island.

The low colonization of AM plants at high latitudes could be explained if either the AM fungi are unable to survive the adverse conditions there, or if the arctic plant hosts are allocating less resources to the symbiosis. Väre et al. (1992) reported that typical AM plants are missing at high latitudes, but in many other cases suitable host plants, for example many grasses, are present even at high latitudes. Smith and Read (1997) state that the low colonization of AM fungi in arctic environments can not be explained solely by the lack of AM plants, since typical host species are also often noncolonized. Instead it seems as if the environment is less suitable for the AM symbiosis or that successful postglacial dispersal differs between AM fungi and AM plants. The short growing season together with frequent disturbance (ice cover for long periods of time) may be of particular importance in this respect together with a high level of climatic stress. We found that the soils at the arctic sites had characteristics typical of sites where AM is common (low organic content and high $\mathrm{pH}$ ). The potential AM activity of the soil was demonstrated by the successful colonization of bait plants in the greenhouse trials, even for sites that had poor AM formation with plants under natural conditions. Sites with high levels of stress at low latitudes may have a high proportion of nonmycorrhizal species as well, as was demonstrated by Olsson and Tyler (2004) for south Swedish rocky habitats.

The AM fungal genus most frequent at arctic conditions appears to be Glomus. No other AM fungal genera have so far been reported from Arctic Canada. Väre et al. (1992) found only one Glomus spore in their study on Svalbard. 
Dalpé and Aiken (1998) extracted AM fungal spores from Canadian Arctic tundra soils and identified four different Glomus species. Glomus was also the dominant AM fungal genus in this study, although we did not investigate the spore communities in detail. Other studies have shown that other AM fungal genera may also be adapted to cold climates. In studies in northern Scandinavia (Väre et al. 1997) and the subantarctic island of South Georgia (Christie and Nicolson 1983), Acaulospora scrobiculata was the most common AM fungus. Investigations of sand dunes on Iceland (Greipsson et al. 2002) revealed that Glomus was the most common AM fungal genus there, but, in addition, three other AM fungal genera were found (Acaulospora, Entrophospora, and Scutellospora).

Our study indicates that fine endophytes are relatively more frequent at high latitudes than AM fungi (Table 1). There are few reports of fine endophytes in Arctic areas, but Väre et al. (1992) found a "thin hyaline mycelium with sclerotia" in Taraxacum arcticum Dahlst. on Svalbard and show a micrograph with hyphae having characteristics typical for fine endophytes (see Fig. 7 in Väre et al. 1992). There seems to be a progressive increase in colonization by fine endophytes compared with AM fungi with altitude in the Alps (Haselwandter and Read 1980), which indicates that these fungi are well adapted for a short growing season and that they are more successful symbionts under adverse conditions. The high percentage of fine endophyte colonization in Trisetum spicatum at Ellesmere Island and in $R$. sabinei at Ellef Ringnes Island could indicate that these fungi are more successful when AM fungi are not present. However, fine endophytes frequently occurred in AMcolonized plants at Banks Island, and hyphae of the two types of fungi occurred in some cases closely together in roots (Fig. 4).

We found dark septate fungi in 7 of the 25 species we studied. Dark septate fungi were observed at all sites of our study. Mainly older roots are colonized (Jumpponen and Trappe 1998), and this could explain why we found colonization by dark septate fungi only in plants sampled in natural habitats and not in the bait plants. Since the symbiosis between plants and dark septate fungi is considered to be a parasitic association, this could mean that only old plants with reduced viability could be colonized.

In conclusion, the high AM colonization in the plants from Banks Island shows that AM fungi may be important for the vegetation formation, at least as far as to the southern end of the Northern Arctic tundra zone. It is not yet possible to state to what degree absence of AM fungi is due to obstacles of dispersal or environmental conditions. However, the combination of the survey and the greenhouse study of the Devon Island suggest climatic conditions rather than absence of inoculum as the reason for low AM colonization in this transition zone. Clearly, typical AM plants, despite absence of AM inoculum, extend further into the Northern Arctic tundra and the Arctic polar zones. We provide further evidence for the fact that fine endophytes are more frequent in harsh climatic conditions than AM fungi, but the functional role of these fungi in plant communities is still to be explored. The high proportion of nonmycorrhizal plant species we found in the investigated vegetation indicates that the $\mathrm{AM}$ association is less important in arctic ecosystems than it is in temperate ecosystems. We suggest that the function of AM under arctic climatic conditions could be investigated experimentally. In microcosm studies, the interactions between nonmycorrhizal and AM plants could be studied with and without AM fungal inoculum, preferably of arctic origin, under varying levels of temperature and freezing and thawing regimes. This could help us better understand the development of plant communities in arctic sites and how these processes are influenced by the presence or not of AM fungi. Furthermore, the study of genetic variation in arctic AM fungal populations could reveal if there are dispersal limitations.

\section{Acknowledgements}

Reidar Elven at Oslo University is acknowledged for help with identification of collected plants. We thank the Swedish Polar Research Secretariat for organizing the expedition. Thanks also to Mats Andersson, Göteborg university, for providing the study site map and to Mayra Gavito for examining the spore community. This work was supported financially by The Swedish Research Council for Environment, Agricultural Sciences and Spatial Planning (Formas).

\section{References}

Angerbjörn, A. 1998. Site manual for Tundra North West 1999. The Swedish Polar Research Secretariat, Stockholm.

Bledsoe, C., Klein, P., and Bliss, L.C. 1990. A survey of mycorrhizal plants on Truelove Lowland, Devon Island, N.W.T., Canada. Can. J. Bot. 68: 1848-1856.

Cabello, M., Gaspar, L., and Pollero, R. 1994. Glomus antarcticum sp. nov., a vesicular-arbuscular mycorrhizal fungus from Antarctica. Mycotaxon, 51: 123-128.

Christie, P., and Nicolson, T.H. 1983. Are mycorrhizas absent from the Antarctic? Trans. Br. Mycol. Soc. 80: 557-560.

Dalpé, Y., and Aiken, S.G. 1998. Arbuscular mycorrhizal fungi associated with Festuca species in the Canadian High Arctic. Can. J. Bot. 76: 1930-1938.

Elvebakk, A. 1999. Bioclimatic delimitation and subdivisions of the Arctic. In The species concept in the high North. Edited by I. Nordal and V.Y. Razzhivin. The Norwegian Academy of Science and Letters, Oslo. Ny Serie No. 38. pp. 81-112.

Francis, R., and Read, D.J. 1994. The contribution of mycorrhizal fungi to the determination of plant community structure. Plant Soil, 159: 11-25.

Francis, R., and Read, D.J. 1995. Mutualism and antagonism in the mycorrhizal symbiosis, with special reference to impacts on plant community structure. Can. J. Bot. 73(Suppl. 1): S13011309.

Gardes, M., and Dahlberg, A. 1996. Mycorrhizal diversity in arctic and alpine tundra: an open question. New Phytol. 133: 147-157.

Gerdemann, J.W., and Nicolson, T.H. 1963. Spores of mycorrhizal Endogone species extracted from soil by wet sieving and decanting. Trans. Br. Mycol. Soc. 46: 235-244.

Greipsson, S., El-Mayas, H., Vestberg, M., and Walker, C. 2002. Arbuscular mycorrhizal fungi in sandy soils in Iceland. Arct. Antarct. Alp. Res. 34: 419-427.

Grime, J.P. 1979. Plant strategies and vegetation processes. Wiley, Chichester.

Harley, J.L., and Harley, E.L. 1987. A check-list of mycorrhiza in the British Flora. New Phytol. 105: 1-102. 
Haselwandter, K., and Read, D.J. 1980. Fungal association of roots of dominant and sub-dominant plants in high-alpine vegetation systems with special reference to mycorrhiza. Oecologia, 45: $57-62$.

Helm, D.J., Allen, E.B., and Trappe, J.M. 1996. Mycorrhizal chronosequence near Exit Glacier, Alaska. Can. J. Bot. 74: 1496-1506.

Johnson, N.C. 1998. Responses of Salsola kali and Panicum virgatum to mycorrhizal fungi, phosphorus and soil organic matter: implications for reclamation. J. Appl. Ecol. 35: 86-94.

Jonasson, S., and Sköld, S.E. 1983. Influences of frost-heaving on vegetation and nutrient regime of polygon-patterned ground. Vegetatio, 53: 97-112.

Jumpponen, A., and Trappe, J.M. 1998. Dark septate endophytes: a review of facultative biotrophic root-colonizing fungi. New Phytol. 140: 295-310.

Kohn, L.M., and Stasovski, E. 1990. The mycorrhizal status of plants at Alexandra Fiord, Ellesmere Island, Canada, a high arctic site. Mycologia, 82: 23-35.

McGonigle, T.P., Miller, M.H., Evans, D.G., Fairchild, G.L., and Swan, J.A. 1990. A new method which gives an objective measure of colonization of roots by vesicular-arbuscular mycorrhizal fungi. New Phytol. 115: 495-501.

Miller Jr., O.K., and Laursen, G.A. 1978. Etcto- and endomycorrhizae of arctic plants at Barrow, Alaska. In Vegetation and production ecology of an Alaskan arctic Tundra. Edited by L. Tiezén. Springer Verlag, New York. pp. 229-237.

Molau, U., Alerstam, T., Danell, K., Eriksen, B., and Graneli, W. 1999. Tundra Northwest 1999: A collaborative challenge in the Arctic. AMBIO, 28: 287-291.

Moore, P.D. 1987. Distribution of mycorrhiza throughout the British flora. Nature (London), 327: 100.

Newman, E.I., and Reddell, P. 1987. The distribution of mycorrhizas among families of vascular plants. New Phytol. 106: 745751.

Olsson, P.A., and Tyler, G. 2004. Occurrence of non-mycorrhizal plant species in south Swedish rocky habitats is related to exchangeable soil phosphate. J. Ecol. 92: 808-815.
Peat, H.J., and Fitter, A.H. 1993. The distribution of arbuscular mycorrhizas in the British flora. New Phytol. 125: 845-854.

Phillips, J.M., and Hayman, D.S. 1970. Improved procedures for clearing roots and staining parasitic and vesicular-arbuscular mycorrhizal fungi for rapid assessment of infection. Trans. Br. Mycol. Soc. 55: 158-161.

Porsild, A.E., and Cody, W. 1980. Vascular plants of continental northwest territories, Canada. National Museums of Canada, Ottawa, Ont.

Read, D.J., and Haselwandter, K. 1981. Observations on the mycorrhizal status of some alpine plant communities. New Phytol. 88: 341-352.

Smith, S.E., and Read, D.J. 1997. Mycorrhizal symbiosis. 2nd ed. Academic Press, San Diego, Calif.

Stoyke, G., Egger, K.N., and Currah, R.S. 1992. Charcterization of sterile endophytic from the mycorrhizae of subalpine plants. Can. J. Bot. 71: 2009-2016.

Tester, M., Smith, S.E., and Smith, F.A. 1987. The phenomenon of "nonmycorrhizal" plants. Can. J. Bot. 65: 419-431.

Thippayarugs, S., Bansal, M., and Abbott, L.K. 1999. Morphology and infectivity of fine endophyte in a mediterranean environment. Mycol. Res. 103: 1369-1379.

Van der Heijden, M.G.A. 2002. Arbuscular mycorrhizal fungi as a determinant of plant diversity: in search for underlying mechanisms and general principles. Ecol. Stud. 157: 243-266.

Van der Heijden, M.G.A., Klironomos, J.N., Ursic, M., Moutoglis, P., Streitwolf-Engel, R., Boller, T., Wiemken, A., and Sanders, I.R. 1998. Mycorrhizal fungal diversity determines plant biodiversity, ecosystem variability and productivity. Nature (London), 396: 72-75.

Väre, H., Vestberg, M., and Eurola, S. 1992. Mycorrhiza and rootassociated fungi in Spitsbergen. Mycorrhiza, 1: 93-104.

Väre, H., Vestberg, M., and Ohtonen, R. 1997. Shifts in mycorrhiza and microbial activity along an oroarctic altitudinal gradient in northern Fennoscandia. Arct. Alp. Res. 29: 93-104. 